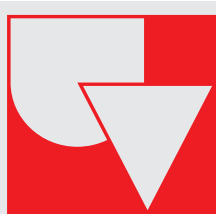

Universidad del Valle

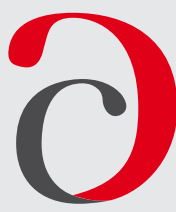

Cuadernos de Administración
Journal of Management

Print ISSN: 0120-4645 / E-ISSN: 2256-5078 / Short name: cuad.adm.

Pages: 4-15 / Vol: 36 / Issue: 67 / May - Aug. 2020

Faculty of Administration Sciences / Universidad del Valle /

Cali - Colombia

\title{
Organizational characterization of craftsmanship in northern of Valle del Cauca
}

\author{
Caracterización organizacional de los artesanos en la región norte del Valle del Cauca
}

\author{
${ }^{1}$ Benjamín Betancourt GuerreroD \\ Full-time professor, Faculty of Administration Sciences, Universidad del Valle, Cali, Colombia \\ e-mail: benjamin.betancourth@correounivalle.edu.co
}

2 Dario José Espinal RuiziD

Head Professor, Faculty of Economics and Administration Sciences, Escuela Nacional del Deporte, Cali, Colombia e-mail: dario.espinal@endeporte.edu.co

\section{${ }^{3}$ Gildardo Scarpetta CaleroD}

Full-time professor, Faculty of Economics and Administration Sciences, Escuela Nacional del Deporte, Cali, Colombia e-mail: gildardo.scarpetta@endeporte.edu.co

Article of Scientific and Technological Research
Submitted: 06/12/2019
Reviewed: 02/03/2020
Accepted: 07/02/2020
Thematic lines: Administration and Organizations
JEL classification: O17
DOI: https://doi.org/10.25100/cdea.v36i67.8730

\begin{abstract}
Young creators, designers, and master artisans are reinventing craftsmanship with their freshness and daring and turning it into a laboratory for sensory, emotional, and symbolic experiences. This paper will present artisans' organizational status in the development of such a profession or craft in the municipalities that are part of the northern region of Valle del Cauca (Colombia). For this purpose, we resorted to documentary analysis and inquiries with stakeholders to characterize the region socially and demographically, for its geographical location, and identifying comparative and competitive advantages in the territory, according to the productive vocation of the municipalities and their relationship with crafts production. Likewise, the research analyzes artisans' capabilities as a dynamizing sector for social, economic, and organizational processes. This study is a preliminary approach because its results are inconclusive, thus allowing other researchers to develop into the importance of the artisanal sector for the socioeconomic development of the northern region of Valle del Cauca. The strategic approaches outlined in this paper are those consolidated with the stakeholders, who have enabled the craft sector's strengthening through innovative proposals regarding the management of their workshops and business units.
\end{abstract}

Keywords: Local Development, Handicrafts, Socioeconomic Aspects, Valle del Cauca, Colombia, Associativity, Entrepreneurship.

Business Administrator, Master's Degree in Administration, Universidad del Valle, Colombia.

2 Professional in Culture and Sports, Ph.D. in Administration, Universidad del Valle, Colombia.

3 Business Administrator, Master's Degree in Administration, Universidad del Valle, Colombia. 


\section{Resumen}

La artesanía está siendo reinventada de la mano de jóvenes creadores y diseñadores, así como de maestros artesanos que, con su frescura y osadía, la convierten en un laboratorio de experiencias sensoriales, emocionales y simbólicas. El presente artículo expone la situación organizacional de los artesanos en el desarrollo de la profesión u oficio de los municipios que forman parte de la región norte del Valle del Cauca (Colombia). Para dicho propósito, se acude al análisis documental y a la consulta de los actores sociales, para la caracterización sociodemográfica de la región, su localización geográfica, se identifican ventajas comparativas y competitivas del territorio, de acuerdo con la vocación productiva de los municipios y su relación con la producción artesanal. Así mismo, la investigación contempla un análisis de las capacidades de los artesanos, como sector dinamizador de procesos sociales, económicos y organizativos. El presente estudio, es una aproximación preliminar, sus resultados no son concluyentes, lo cual permite que surjan otras investigaciones que profundicen, acerca de la importancia que tiene el sector artesanal en el desarrollo socioeconómico de la región norte del Valle del Cauca. Las líneas estratégicas aquí establecidas, son aquellas que se consolidaron con los actores, quienes han de permitir fortalecer al sector artesanal mediante propuestas innovadoras para la gestión de sus talleres y unidades de negocio.

Palabras clave: Desarrollo local, Artesanía, Aspectos socioeconómicos, Valle del Cauca, Colombia, Asociatividad, Emprendimiento.

\section{Introduction}

Craftmanship is perhaps one of humankind's oldest trades. These are handmade objects out of different materials such as wood, clay, stone, vegetable fibers, leather, resins, among others, a trade that has survived throughout history (Sennett, 2009; Granda, 2016). In fact, handicraft producers are renowned as expert processors and weavers of vegetable fibers, highly-skilled woodcarvers, creative designers of seed necklaces and bracelets, and exceptional cartoonists (Chaves, Montenegro, and Nova, 2019).

All these skills synthesize traditional knowledge that is adapted to market demands. Nevertheless, nowadays, more importance is placed on industrially made products, setting aside artisans' contributions. However, as industrial sectors reinvent themselves, they are turning to the proposals of artisans. An example of the preceding is the world of design, which is continuously rediscovering itself from different perspectives and making its own the emotional, sensory, and social values contained in artisans' knowledge (Turok, 2013). This brings diversification to handicrafts demand in different markets, using commercial channels and differentiated communication strategies (Balza and Cardona, 2016). Some artisans have reconsidered their activity from a socio-cultural perspective through training, outreach, and leisure workshops, as well as by engaging in thematic markets, activities whose demand is growing. Nevertheless, this alternative is not satisfactory for those who are more committed to creative activities (Navarro, 2016).

Therefore, it becomes necessary to study the phenomenon of craftmanship, especially in territories and populations whose livelihood revolves around this activity. Hence, the characterization thereof is vital for the design of public policies that promote local development and the craft sector. On the matter, local development could be a viable alternative that must be worked on regarding discourses and community-context practices so that the territorial, cultural, and social dimensions stand out as central axes for development. Local development with the craft sector as its driving axis entails the gearing of projects focused on improving the quality of life of Valle del Cauca's northern population, where the collective bets of the communities of craftsmen play an essential role in social articulation processes and with State (Betancourt, Azuero, and Martínez, 2010).

Handicrafts are one of the cultural products rooted in Latin American tradition and popular culture (Ministerio de Comercio and Industria y Turismo, Artesanías de Colombia, 2012; Molina, 2012 ). Its diversity and expressive richness speak of the ethnic and multicultural mosaic of the region's peoples, customs, beliefs, and ways of life. Today's Latin American crafts sector develops amid highly complex economic and social events (Hudson, Silva, and McEwan, 2016). As a product, its cultural scope is limited by conceptions that classify it as a minor art, reserving the highest aesthetic-social considerations only for professional arts, and by being appreciated only for its trading value. This when they become vulnerable to 
overexploitation by a market that subjects crafts to banalization and loss of identity (Brewer, 2017).

In Colombia's handicraft sector, over 350,000 people are engaged in craftrelated trades, accounting for $15 \%$ of the manufacturing industry (Agenda Interna para la productividad y competitividad, 2007). The population of craftsmen consists mainly of heads of households, $60 \%$ women and $40 \%$ men. By trade, 57.5\% are devoted to weaving in its various forms. The rest is engaged in woodwork $(13.5 \%)$, pottery $(9.8 \%)$, leather goods (3.5\%) and jewelry (2.4\%) (DANE, 2018; Artesanías de Colombia 2013; Garrido and Valderrama, 2016).

The subject matter of this research is the organizational characterization of craftsmen in northern Valle del Cauca. The work concentrated in the municipalities that make up this region due to the progressive strengthening of their handicrafts and their contribution to other related sectors such as tourism, gastronomy, hospitality, and culture, consolidating a vital tourist route around its climate, landscapes, historical sites, beautiful places, diversified activities or events, and regional elements perfect for holidays or frequent as a tourist place (Cámara de Comercio de Cartago Valle del Cauca, 2017).

However, northern Valle del Cauca's crafts sector faces issues as identified by its stakeholders. Such issues relate to lack of support from the State, lack of articulation between academia and the sector, inconsistent quality in production, lack of knowledge on the market, trends, and ways to reach new customers through innovative products, high production costs, and deficient workshop management. On the other hand, State agencies attach little importance to the crafts sector's socio-economic and cultural impact on regional development and related aspects. These include intense competition with industrial products, low recognition given to artisanal products (which prices reflect), an unconsolidated productive chain between suppliers, artisans and the market, and the lack of interest of craftsmen themselves in consolidating their associations or guilds, among others (Scarpetta and Betancourt, 2019).
The synergy between tourism and handicrafts sectors (Muñoz Jacome, Esparza, Gaibor, and Torres, 2014), as a local development factor boosts local economies, promotes equality, generates employment, and also contributes to spreading the country's history, heritage values, knowledge and culture to Colombians themselves and the world (Lugo-Morin, Magal-Royo, and Shinn, 2015). Crafts in the region are an expression of identity and cultural value that can be made known within and outside the country through tourism (Mendoza Tarabó, Ramírez Frías, Yumisaca Tuquinga, and Peralta Mendoza, 2019). Moreover, tourism is an opportunity to support social and economic development in local craftproducing communities (Forstner, 2013).

Another theoretical reference to support our research process is that proposed by Porter and his Competitive Diamond model. This model allows addressing sectoral issues from the factors involved in the production of goods and services, the productive chain, demand, the sector's organizations and strategies, the State's intervention, and the uncertainties of the future. Thus, the sectoral approach allowed the identification of existing synergy between handicrafts and other related actors (Betancourt, 2014).

The methodology combined qualitative and quantitative methods. The development strategy of the project conceived two articulated phases. The first phase is diagnostic and for characterization. The variables' characterization was carried out through the processing of information from primary sources and consultation with the region's stakeholders. Porter's Competitive Diamond model allowed us to approach the sector's problem and outline the environment wherein the handicraft sector develops in northern Valle del Cauca. The Diamond methodology helped explain the regional environment in which craft organizations exist, learn how to compete, and how they collaborate and compete. In the geographical context of northern Valle del Cauca, this sector consists of a significant number of small organizations and formal workshops that produce and provide services across the different lines of craftmanship. The diamond model becomes 
a point of reference because it is the crafts sector, the economic unit under study, where comparative and competitive advantages are built in the region. The preceding allowed the researchers to use it as a learning tool and understand the dynamics resulting from the interaction of four attributes: productive factors, productive chains, the demand's conditions, and craft sector's organizations and workshops' strategy and structure (Betancourt, 2014).

The second phase, the consolidation of strategies, posited strategic lines, and goals in a comprehensive manner that will help consolidate long-term projects and plans. Finally, some conclusions derived from the main findings of the research are presented.

\section{Methodology}

From the standpoint of research, our methodology is conceived as a combination of qualitative and quantitative strategies (Villasante and Montañés, 2001) that led to an exercise where stakeholders took part.

To achieve such an objective, an exploratory/ descriptive study was conducted using a working sample consisting of 25 leaders from associations and independent artisans regarded as traditional artisans and craft workshops managers. All were knowledgable in their specialty of craftsmanship and had demonstrated originality and creativity in their techniques, design, and production.

This sample was non-probabilistic because, at the researchers' discretion, the selected people's perception can provide the information required for this analysis according to the project's intention (Jury, 2011).

The instrument applied was structured with the necessary seven (7) key variables to examine the sociodemographic, socioeconomic characteristics, crafts production, social organizations, craftsmanship-related projects, institutional framework, and environment. To this end, we employed the guides by Sánchez, Jiménez, Carbajal, and Acosta (2007) and Jurado (2011) because they delimited some recognized practical parameters for this type of research.
The development strategy of the project conceived two phases, the first one being Diagnosis and Characterization. The characterization of the variables was carried out through the processing of information from sources referred to in the consultation with the region's stakeholders and artisans directly engaged in the production process, as well as the use of reading nets, in-depth interviews, fieldwork and systematization of information (Betancourt et al . 2010). For the documentary analysis, institutions such as Handicrafts of Colombia, the Chamber of Commerce of Cartago, National Planning Department, the National Administrative Department of Statistics (DANE per its acronym in Spanish), and the Ministry of Commerce, Industry, and Tourism were consulted with.

The second phase was strategy consolidation. Strategic lines and goals are established for craftsmen's organization in such a way as to consolidate programs that seek to incorporate them into the development plans of their municipality.

\section{Results of the diagnosis and characterization of craftsmanship in northern Valle del Cauca}

The data obtained through the instrument applied at this stage are the benchmark for analysis through the Competitive Diamond model's structure. This will allow addressing sectoral issues from the perspective of the factors involved in the production of goods and services, the chain of production, the demand, sector's organizations and strategies, intervention by the State and future uncertainties as the handicrafts sector faces in northern Valle del Cauca (Betancourt, 2014; Mejía, 2018).

\subsection{Endowment and conditions of factors}

Human resources:
qualification, and costs of personnel
including management). (+) For the whole (including management). (+) For the whole
of the population surveyed, nine (9) had finished elementary school, five (5) went to secondary school, and three (3) achieved a technical secondary education level. 
Having people with access to educational opportunities means for Colombians that the artisanal sector will have skilled labor for the administrative, technical, and marketing management of products.

( +) An analysis of the age group of the craftsmen surveyed shows a population economically active in the craft business that ranges from 42 years to 60 years of age. Furthermore, crafts-related activities are carried out by men (60\%). However, the importance of the women (40\%) committed to this art stands out, for they make it possible to strengthen the craftsmanship and technique put into products.

(-) Craftsmen's residences are located in urban areas (52\%), rural areas (40\%), and indigenous protection areas (8\%). Participation by the population of artisans concentrated in urban and rural areas is representative. In the municipalities, 36\% of the population surveyed recognized themselves as white, $28 \%$ as mixed-race, $20 \%$ as African-descent, and $16 \%$ as indigenous. This indicates that the region where craftsmanship is practiced is a multicultural and multi-ethnic area.

Physical resources: abundance, quality, accessibility, and costs of elements such as land, water, mineral deposits, wood reserves, among others. (-) When purchasing raw materials, artisans face difficulties in developing their activities fully. In this vein, 55\% of respondents lack money, $14 \%$ cannot procure enough supplies, $11 \%$ are affected by the cost of materials, and there being few suppliers, while $6 \%$ by shortages of raw materials and $3 \%$ by lack of credit. The type of raw materials for crafts making is a determining factor in the quality and originality of the products. In this regard, $50 \%$ of respondents use plant material, $21 \%$ synthetics, $14 \%$ minerals, $12 \%$ animal-sourced materials, and only $3 \%$ employ recycled materials.

Knowledge resources. (+) Internet providers: Valle del Cauca procures its Internet service through national service providers, interconnecting the department with the rest of the world.

(+) Information Center for International Trade: Procolombia, an entity attached to the Ministry of Trade, Industry, and Tourism, supports entrepreneurs prepared to engage in international trade.

(-) Development of databases: it is not a significant strength in Valle del Cauca. Moreover, few entities do this work and, therefore, accessing these data is not common.

Financial Resources. (-) The Banco Agrario (Agricultural Bank), Bancoldex, and the Social Bank program of Valle del Cauca's Governorate provide lines of loans with interest rates that benefit artisans. Nevertheless, there is a widespread lack of knowledge about the different loans that various financial institutions provide in the nuclei of artisans.

\subsection{Classification of factors Basics}

Among the underlying factors, there is:

(-) Raw materials' limited sustainability: some raw materials used in the products' development depend on a particular production process. Hence, if the growth of these raw materials goes unsupported, the resource's availability could be affected.

(-) Raw materials procurement issues: artisans focus on artisanal work and are unaware of the remaining production process of their raw material. In general, they lack a database with suppliers and use thereof for their work.

(-) Negative impact on the forest: carving in wood, lathe, vegetable ivory, and bamboo means that timber products are used as raw material, thereby affecting tree species. If not reforested, forests will take several years to recover or lead species to the brink of extinction in the worst-case scenario.

(-) The unfavorable geographical location for marketing: the Department of Valle del Cauca, though favored with routes for the transport of goods, prices increase as these are distributed to the rest of the country due to distances traveled, thereby hindering the products' competitiveness in the domestic market.

(-) Non-skilled labor: some workshops demand training in this trade, for workers 
are not undergoing the appropriate training to address the demand for products.

\section{Advanced}

\section{Infrastructure:}

Artisans are characterized by offering the following services:

(-) Land transport only.

(+) Proximity to an airport for freight transport.

(+) Adequate communication networks.

(+) Health care and drinking water services available to all inhabitants of the city.

(+) Logistic networks and so on.

(+) Artisans have drinking water, electricity, and gas to develop their daily crafts-related activities.

\section{Communications}

(+) Crafts-related activities, coupled with ICTs, make it possible to strengthen the sector by commercializing its products.

\section{Specialized staff}

(-) Although Artesanías de Colombia (Handicrafts of Colombia) owns workshops where it provides technical training in connection to the trade, its presence in the region is not strong enough, which makes interactions between artisans and professionals difficult.

(-) Artisans must be trained to strengthen their organizational management, production, and marketing processes.

\section{Advanced Managerial Training}

(-)Thesector's degree of professionalization is little. The commercialization of crafts is an activity developed by craftsmen. Sometimes, they are the ones who produce and market by themselves. As such, their marketing ways are distributed as follows: $76 \%$ sell directly to the consumer, $12 \%$ do so at points of sale, and $4 \%$ use intermediaries.

Institutes and research centers for the sector.
(-) Concerning the learning process of craftsmanship, it turns out that $24 \%$ of the respondents gained their knowledge or learned the craft by themselves or from a fellow craftsman. In comparison, $17 \%$ were taught by someone in the family, $12 \%$ underwent training in an institution, $10 \%$ learned at a handicraft workshop, and 3\% have a related degree.

Appropriation, development and proper use of information, knowledge, and technology

(-) Studying the tools artisans use to make their products revealed that $54 \%$ use their hands, $27 \%$ employ hand tools, $11 \%$ have support from simple machines, and $8 \%$ from powered machines.

\section{Specialties (supporting the sector)}

(+) Chemical companies constitute support because they allow better finishes.

\section{Related supporting sectors, networks, productive chains and clusters}

(-) Inquiring about participation in a social organization or collective group, respondents explained that they do not belong to one due to lack of information (48\%), only a few benefit (20\%) or because these do not aid in production (8\%), while the rest did not respond.

(-) About $68 \%$ of artisans have an independent room within their house to develop their craft, which allows them to make the most of their time, and improves productivity and competitiveness, commonly known as "house - workshop." This entails savings in terms of lease fees, but it also makes it difficult for them to display their products because there is no room for marketing and direct sale. On the other hand, $20 \%$ of the population surveyed has a business place, which facilitates the product displaying for marketing and direct sale purposes.

(-)Raw materials are purchased individually, and there is a lack of knowledge that suppliers could provide artisans a competitive advantage by offering discounts and lowering prices.

(-) Digital marketing is healthy; however, the sector lacks sufficient knowledge for 
appropriate use. Therefore, the sector should rely on knowledgeable companies in the field to improve the marketing of handicrafts.

\subsection{Conditions of the Demand}

(+) Some craftsmen develop a variety of crafts-related trades, wherefore customers are presented with a diversified offer of products.

(+) Cartago's embroidery has participated in the International Embroidery Fair in Miami. Likewise, this city hosts two events: one in the framework of the festivities or fairs and the other during Easter.

(+) Artesanos de Colombia (Handicrafts of Colombia) offers artisans direct participation in fairs and events, puts them in touch with clients, and provides information based on market research and information on trends, marketers, and potential customers.

(+) Since handicrafts are an expression of popular art, they are linked to tourism and diversity because people become interested in the regions' cultural products while on their break.

(+) The business opportunities created by Artesanías de Colombia permit artisans access to strategic spaces that tourists visit.

\subsection{Strategy, structure, and rivalry}

(-) Craftsmanship needs to be transmitted by generation in order to preserve techniques over time. Concerning the learning process of craftsmanship, it turns out that $24 \%$ of respondents gained their knowledge or learned the craft in a by themselves or from a fellow craftsman. In comparison, $17 \%$ were taught by someone in the family, $12 \%$ underwent training in an institution, $10 \%$ learned at a handicraft workshop, and 3\% have a related degree.

\subsection{The Government (management)}

(+) Colombia has a series of trade agreements and treaties for greater transactional ease. Trade agreements facilitate the commercialization of goods and services and can be harnessed to conduct business abroad.

(-) Inadequate protection for artisans. There is no public policy to boost the crafts sector economically, socially, or educationally.

(+) Entities at the service of the crafts sector. According to Law 36 of 1984, the organizations that support craftsmanship are artesanías de Colombia and SENA (National Learning Service).

\subsection{Randomness}

(+) Colombia's geographical position, together with its natural characteristics, enables varied types of tourism. The crafts sector makes it easy for visitors to admire its technique by witnessing production processes and acquiring the finished products. The variety of techniques developed in Colombia allows the positioning of some trades above others, prompting the laggers to improve and innovate so as not to lose the tradition.

(+) The department of Valle del Cauca is characterized by the development of craftsmanship techniques that shape its tourist appeal. Besides constituting the producers' income, craftsmanship has become a tourist attraction and a region's cultural representation over time.

\section{Consolidation of strategic lines to strengthen the crafts sector in northern Valle del Cauca}

The strategic component proposes key lines and goals to consolidate long-term projects and plans aimed at strengthening social, economic, and environmental actions through education, knowledge, and development, seeking to incorporate them into the municipalities' development plans (Barrera, 2011; Mejía, 2018).

\section{Strategic line one: craftsmanship quality proposal}

It refers to supporting or strengthening craftsmanship based on new product design and organizational structure, through each stakeholder linked to the production chain 
(Luva de Mello and Ciliane Ceretta, 2015; Ciliane Ceretta, Zamberlan dos Santos, and Flores dos Santos, 2014).

At this point, the raw material used must be environmentally friendly and the surplus, where possible, recycled for the benefit of the community where the work takes place. This is to be able to show the product internationally (Amaya, 2017), (Lee and de Long, 2017).

It is essential to get artisans to exchange knowledge, crafts-specific technology, and supporting technologies among themselves, i.e., to have the function of the subject matter, aesthetics, and its cultural significance embedded in the package to be offered (Soukhathammavong and Park, 2019; Luckman, 2018).

\section{Target for strategic line one: a quality proposal for crafts}

Procuring and managing alliances oriented to the processing of framework agreements in the mid-and-long-term with public and private institutions committed to the development of craftsmanship (Gómez, and Betancourt Guerrero (2012).

To strengthen processes at the technical, organizational, and associative levels through managerial, administrative, and commercial components with a view towards growth and other markets (Arango, 2013).

Improving technological processes through Artesanías de Colombia by expanding the source of knowledge, and generating and adopting new technologies, preserving and improving existing technologies within the framework of rescuing, preserving and developing handicrafts as part of the country's cultural heritage ( Álvarez, García, and Orrego, 2015).

To consolidate crafts' value chains as to include components such as research and development, adequacy of raw materials, human and business development, technical assistance, innovation and design, and production and marketing, through a participatory approach and in partnership with artisans and professional teams ( Ok, 2014; Castro Escobar, Ramírez Ospina, and Serna Gómez, 2018).
To articulate young people, women, and social groups under special conditions through knowledge and skills that complement artisans' work, involving ICTs and social networks, among other technological tools (Kaya, 2015; Hamann and Mejía (2013).

To further the proposition of activities that guarantee the sustainability of the raw materials that support craftsmanship. As such, the projects to be formulated will include these initiatives in their logical frameworks (Babbie, 2010).

It is essential to work on strengthening associations and workshop integration, which would improve the demand for raw materials, inputs and complements to improve purchased volumes, thereby making the crafts sector attractive (Batista-Canino, Bolívar-Cruz, and Medina-Brito, 2016; Galvis, 2010).

To train population groups in craft-related trades in order to promote the creation of new roots that increase the labor required by crafts production chains in their development (Natário, Braga, and Fernandes, 2018)

\section{Strategic line two: large-scale marketing}

It focuses on large-scale marketing and develops a proposal that generates options and increases labor supply in trades that have managed to position themselves in the market and require generational renewal. Such a proposal will also increase labor demand due to the market's high demand for products( García-Cabrera, García-Soto, and Días-Furtado, 2015).

The above should be aimed at supporting artisans in conceiving a useful-at-home craft, as the evidence showed; it must be appropriately useful with a view towards the future, and its recycling should benefit the community after it has been used (Arbuthnott and von Friedrichs, 2013).

The target for strategic line two: large-scale marketing

To identify opportunities that enhance diversification capabilities of local, regional, and national marketing spaces for artisans; particular emphasis is placed on fair trade (Bustos, 2016; Ropero, 2015). 
To participate in different activities taking advantage of tourist locations offered by the department of Valle del Cauca such as religious, cultural, gastronomy, and festivals tourism to create new spaces for displaying and marketing, and coupled with strategies and training plans for customer service (Avila, 2018).

To identify and establish links with financial institutions that support craftsmanship through lines of credit to strengthen production processes in terms of innovation concerning color techniques, drawings, designs, shapes, and new figures (Ahmad, 2014 ).

To consolidate trading intermediaries for different trades and have them be responsible for the transaction of goods, while artisans occupy themselves with production and strengthening quality (Stalp and Winge, 2017).

\section{Strategic line three: institutional strengthening}

The third strategic line provides institutional strengthening and seeks to improve the operability and sustainability of Artesanías de Colombia's projects. As such, it would seek to increase the State's investment and that by the cooperation units (Albuquerque, 2011 ), that invest in the development of the crafts sector in northern Valle del Cauca.

\section{The target for strategic line three: institutional strengthening}

Improving the crafts sector's performance by strengthening innovative thinking, and the commitment and growth of human capital in search for results that contribute to the socio-economic development of the region (Fernández de Paz, 2015).

To strengthen craftsmen's empowerment and enhance their skills and technical and productive capabilities at the local, regional, and national levels.

To promote proper management of natural resources and raw materials in order to contribute to environmental sustainability and the preservation of trades in communities of craftsmen.
To strengthen the positioning of craftsmanship before its stakeholders as well.

\section{Conclusions}

In the opinion of those who purchase crafts, their value is embedded in the origin or cultural identity of those producing them and is generally associated with traditional lifestyles. In the case of handicrafts in northern Valle del Cauca, there is excellent potential given their multicultural richness, which represents a more significant challenge in searching for an identity that differentiates them at the national level.

The range of craftmanship in northern Valle del Cauca is broad. From it, products such as tablecloths, blouses, handembroidered dresses, weaving, seed, bamboo, wood carving, and elements from traditional culture and values stand out.

Artisans do not have a formal union organization that allows them to work associatively for better productivity.

Similar industrialized products are on the market at a low cost, making it difficult for them to compete.

The crafts sector in northern Valle del Cauca is vital in generating employment and improving the quality of life of a population that revolves around craftsmanship.

Craftsmanship is part of the cultural heritage that represents the traditions and customs of a region, wherefore the State, through public policy, must seek to dynamize this sector from local, social, economic, educational development, and preservation of the environment.

The crafts sector, academia, and institutions that provide training for work and human development should work together in order to strengthen the trade concerning management, marketing, cost structures, and information systems.

Another issue evidenced is the lack of integration and articulation into a productive chain in order to gain more significant spaces and advantages in the production and marketing of products and, therefore, in local development. 
Around northern Valle del Cauca's craft sector exist sub-records of which there are no formal statistics, which made it necessary to turn directly to them for the characterization and formulation of lines of action.

This subregion is characterized by having places that enjoy cultural and historical heritage at the birth of the department of Valle. Furthermore, through each craft, ethnic richness from each place manages to tell the history and the rich biodiversity of the lands.

To improve the product, it is necessary to have a designer who supports the production of today's pieces and products defined after the needs of the market. The foregoing means goods that interest young users, who will be committed and compelled to maintain and encourage the evolution of the material culture, preserving its cultural identity.

\section{Conflict of interest}

The authors declare no conflict of interest.

\section{Source of Financing}

Universidad del Valle's Research Office sponsored this Research (Analysis to Manager-Academic in Colombia: a study from Organizational Behavior and Knowledge Universidad del Valle's Research Office sponsored this Research (Organizational characterization of craftsmanship in northern of Valle del Cauca).

\section{References}

Departamento Nacional de Planeación (DNP). (2007). Agenda interna para la productividad y competitividad, documento regional Valle del Cauca. Bogotá, Colombia: DNP.

Ahmad, M. (2014). Las relaciones entre los valores personales, culturales, profesionales y la ética del marketing entre los académicos. Procedia Ciencias Sociales y del Comportamiento, (130), 273-281.

Alburquerque, F. (2011). Fundamentos del Desarrollo Local. España: Editorial Académica Española.
Alvarez, J. F., Garcia, Z. H., y Orrego, A. (2015). Marco para el fomento solidaria en territorios de Colombia. Bogotá, Colombia: Rempe Colombia S.A.S.

Amaya Téllez, J. L. (2017). Consumo simbólico de artesanía. Dimensión Empresarial, 15(1), 105120. https://dx.doi.org/10.15665/rde.v15i1.768

Arango, R. (2013). El G11, un esfuerzo de todos los vallecaucanos. Revista Acción, 12(150), 3-4. Recuperado de https:// www.ccc.org.co/contenidoscrecer/ visionario-cambio-chip-del-emprendedor/

Arbuthnott, A., \& von Friedrichs, Y. (2013). Entrepreneurial renewal in a peripheral region: the case of a winter automotive-testing cluster in Sweden. Entrepreneurship \& Regional Development, 25(5-6), 371-403. http://dx.doi.or $\mathrm{g} / 10.1080 / 08985626.2012 .748095$

Artesanías de Colombia (2013). Los artesanos colombianos presentes en la Cumbre de las Américas. Recuperado de http://www. artesaniasdecolombia.com.co:8080/PortalAC/ Noticia/los-artesanos-colombianos-presentesen-la-cumbre-de-las-americas 2184

Avila, A. (2018). La Tele letal con Ariel Avila. Recuperado de Youtube. https://www.youtube. com/watch?v=RcODqz4sruc

Azuero, A., Betancourt, B., y Martínez, R. (2010). Región socialmente responsable, norte del Cauca. Cali, Colombia: Editorial Universidad del Valle. Recuperado de https://www.researchgate.net/ publication/277732870

Babbie, R. (2010). The practice of social research (12 edi., pp. 400-418). Belmont CA, USA: Wadsworth Publications.

Balza, V., y Cardona, D. (2016). Economías de aglomeración empresarial y políticas públicas de competitividad desde un enfoque global hacia un contexto latinoamericano: Una revisión conceptual. Revista Espacios, 37(36), 8. Recuperado de https://www.revistaespacios. com/a16v37n36/16373608.html

Barrera, G. (2011). Campos de poder artesanales en la comunidad Kamsá de Sibundoy, Putumayo, Colombia. Del trueque a las tendencias de moda. Apuntes 24(2), 178-195. Recuperado de http:// www.scielo.org.co/pdf/apun/v24n2/v24n2a05. pdf

Batista-Canino, R. M., Bolívar-Cruz, A., y MedinaBrito, P. (2016). Monitorización del proceso emprendedor a través del modelo de negocio. Innovar, 26(61), 83-101. https://doi.org/10.15446/ innovar.v26n61.57168 
Betancourt, B. (2014). Análisis Sectorial y Competitividad. Bogotá, Colombia: ECOE Ediciones. Recuperado de https:/l www.ecoeediciones.com/wp-content/ uploads/2015/07/An\%C3\%A1lisis-sectorial-ycompetitividad-1.pdf

Brewer, B. D. (2017). Making the 'handmade'bike and trying to make a living: market objects, field-configuring events and some limits to market making. Consumption Markets \& Culture, 20(6), 523-538. https://doi.org/10.1080 $\not 10253866.2017 .1331646$

Bustos, J. (2016). Cali y el Valle del Cauca en la globalización económica: Respuesta regional y su posición en la red de ciudades globales. Cali, Colombia: Universidad del Valle.

Cámara de Comercio de Cartago Valle del Cauca. (2017). Observatorio Económico del Norte del Valle. Recuperado de https://camaracartago. org/Archivos/Contenido/Archivos/2pz5vds047informe-economico-2016-o.E

Ciliane Ceretta, C., Zamberlan dos Santos, N. R., y Flores dos Santos, V. (2014). La valoración de las artesanías en el sur de Brasil a través del turismo. Estudios y Perspectivas en Turismo, 23, (4), 668-684. Recuperado de https://www. redalyc.org/pdf/1807/180732145002.pdf

Chaves, M., Montenegro, M., y Nova, G., (2019). Orgullo y prejuicio en la identidad de marca. Club Colombia y la valorización de la producción artesanal indígena. Ciencias Sociales y Humanidades, Instituto Colombiano de Antropología e Historia, 6(1). http://dx.doi. org/10.36829/63CHS.v6i1.\%25

Departamento Administrativo Nacional de Estadística - DANE (2018). Medición de empleo informal y seguridad social. Trimestre móvil noviembre 2017- enero 2018. Recuperado de https://www.dane.gov.co/files/investigaciones/ boletines/ech/ech_informalidad/bol_ech informalidad_nov17_ene18.pdf

Castro Escobar, E. S., Ramírez Ospina, D. E., y Serna Gómez, H. M. (2018). Ventas informales en el espacio público en Villavicencio (Colombia). Semestre Económico, 21(46), 141-166. https:// dx.doi.org/10.22395/seec.v21n46a6

Fernández de Paz, E. (2015). La Valorización Artesana y su Repercusión Turística. El Caso de Chile Pasos. Revista de Turismo y Patrimonio Cultural, 13(2), 375-393. https://doi. org/10.25145/j.pasos.2015.13.027

Forstner, K. (2013). La artesanía como estrategia de desarrollo rural: El caso de los grupos de artesanas en la región de Puno (Perú).
Cuadernos de Desarrollo Rural, 10(72), 141-158. https://doi.org/10.11144/Javeriana.cdr10-72. aced

Galvis, L. (2010). Diferencias salariales por género y región en Colombia; Una aproximación con regresión. Revista de Economía del Rosario, 13(2). Recuperado de https://www.urosario.edu. co/urosario files/f7/f74319db-9912-4878-a8192eddf54663e-2.pdf

García-Cabrera, A. M., García-Soto, M. G., \& DíasFurtado, J. (2015). Emprender en economías emergentes: el entorno institucional y su desarrollo. Innovar, 25(57), 133-155. https://doi. org/10.15446/innovar.v25n57.50357

Garrido, D., Valderrama, E. (2016). Identificación de las ideas de negocio para la creación de empresa en la población desplazada de Florencia, Colombia. Revista de Investigación, Desarrollo e Innovación, 7(1), 37-48. https://doi. org/10.19053/20278306.v7.n1.2016.5634

Gómez, U. A., y Betancourt Guerrero, B. (2012). Caracterización del sector de las mipymes de Sevilla y Caicedonia, identificación de las prácticas organizacionales predominantes. Cali, Colombia: Programa Editorial Universidad del Valle.

Granda, O. (2016). Paseo por las artesanías de Nariño. San Juan de Pasto, Colombia: Editorial Morada.

Hamann, F., y Mejía, L. F. (2013). Formalizando la informalidad empresarial en Colombia. Bogotá, Colombia: Banco de la República. Recuperado de https://repositorio.banrep.gov. co/handle/20.500.12134/6577

Hudson, C., Silva, M. I., \& McEwan, C. (2016). Tourism and Community: An Ecuadorian Village Builds on its Past. Public Archaeology, 15(2-3), 65-86. https://doi.org/10.1080/14655187 .2017 .1384982

Jurado, Y. (2011). Metodología de la investigación. Ciudad de México, México: Esfinge.

Kaya, Ç. (2015). Desarrollo de nuevos productos a través del diseño: el caso de las artesanías en mardin. millî folklor, 27(106).

Lee, Y. K., \& DeLong, M. (2017). American and Korean youths' attachment to handcraft apparel and its relation to sustainability. Clothing and Textiles Research Journal, 35(2), 67-80. https:// doi.org/10.1177/0887302X16679270

Luckman, S. (2018). Craft entrepreneurialism and sustainable scale: resistance to and disavowal of the creative industries as champions of capitalist growth. Cultural Trends, 27(5), 
313-326. https://doi.org/10.1080/09548963.201 8.1534574

Lugo-Morin, D. R., Magal-Royo, T., y Shinn, C. (2015). Ambiente y artesanía: Sinergia para el desarrollo rural sustentable. Spanish Journal of Rural Development, (January), 57-64.

Luva de Mello, Carolina, y Ciliane Ceretta, Caroline. (2015). El souvenir artesanal y la promoción de la imagen del lugar turístico. Estudios y perspectivas en turismo, 24(2), 188204. Recuperado de http://www.scielo.org.ar/ scielo.php?script=sci arttext\&pid=S1851$17322015000200001 \& \ln g=$ es\&tlng $=$ es

Mejía, P. (2018). Líneas estratégicas 2018 -2023, para cinco núcleos artesanales del departamento de Nariño, atendidos por artesanías de Colombia (Tesis maestría). Universidad del Valle, Universidad de Nariño, Colombia.

Mendoza Tarabó, A., Ramírez Frías, C., Yumisaca Tuquinga, J., y Peralta Mendoza, S. (2019). Artesanías autóctonas como atractivo turístico en la provincia de Santa Elena, Ecuador. Explorador Digital, 3(2), 5-15. https://doi. org/10.33262/exploradordigital.v3i3.415

Ministerio de Comercio, Industria y Turismo, Artesanías de Colombia. (2012). Estudio ocupacional de los subsectores artesanales de tejeduría y cerámica - alfarería (4aㅡ edi.). Bogotá, Colombia: Artesanías de Colombia. Recuperado de https://repositorio.artesaniasdecolombia. com.co/handle/001/2464

Molina, L. (2012). Una caracterización del artesano en Cali. (Trabajo de grado para optar al título de Socióloga). Universidad del Valle, Colombia.

Muñoz Jacome, E., Esparza, D., Gaibor, V., y Torres, C. (2014). Rutas Turísticas: Alternativa Productiva Ecosocial para la Gestión Sostenible de Microcuencas Alto Andinas Estudio de Caso: La Ruta Purina Kunan en La Provincia de Chimborazo Ecuador. Recuperado de https:// eujournal.org/index.php/esj/article/view/4832

Natário, M. M., Braga, A. M., y Fernandes, G. P. (2018). Determinantes do desempenho empreendedor e inovador nas regiões transfronteiriças. Innovar, 28(70), 39-54. https:// dx.doi.org/10.15446/innovar.v28n70.74445
Navarro, S. (2016). La artesanía como industria cultural: desafíos y oportunidades. Bogotá D.C., Colombia: Pontificia Universidad Javeriana.

Ropero Beltrán, S. (2015). Desarrollo Rural en Colombia: entre la realidad y la oportunidad en el posconflicto. Perspectivas Rurales, 27, 1335. Recuperado de https://www.revistas.una. ac.cr/index.php/perspectivasrurales/article/ view/7608

Sánchez, C., Jiménez, L., Carbajal, D., y Acosta, M. (2007). La calidad, su gestión estratégica y sus indicadores en turismo. Hacia una aproximación teórica. Contribuciones Científicas GEA, 19. Recuperado de http://gaea.org.ar/ contribuciones/contribuciones vol19 SanchezJimenez.pdf

Sennett, R. (2009). El artesano. Barcelona, España: Anagrama.

Soukhathammavong, B., \& Park, E. (2019). The authentic souvenir: ¿What does it mean to souvenir suppliers in the heritage destination? Tourism Management, 72, 105-116. https://doi. org/10.1016/j.tourman.2018.11.015

Scarpetta, G., y Betancourt, B. (2019). Caracterización social y organizacional del sector artesanal en la región norte del Valle del Cauca (pp. 73-84). Cali, Colombia: Editorial Escuela sin Fronteras.

Stalp, M. C., \& Winge, T. M. (2017). If at first you don't succeed, rip it out and try again: The benefits of failure among DIY handcrafters. Clothing Cultures, 4(2), 87-104. https://doi. org/10.1386/cc.4.2.87 1

Turok Wallace, M. (2013). Análisis social de los artesanos y artesanas en Latinoamérica. Revista Artesanías de América, (73), 22-29. Recuperado de http://documentacion.cidap.gob.ec:8080/ handle/cidap/1574

Vale, G. M. V., Corrêa, V. S., \& Reis, R. F. (2014). Motivations for entrepreneurship: necessity versus opportunity? Revista de Administração Contemporânea, 18(3), 311-327. https://doi. org/10.1590/1982-7849rac20141612

Villasante, T., \& Montañés, M. (2001). Prácticas locales de creatividad social. Construyendo ciudadanía. Madrid, España: Ediciones el Viejo Topo.

How to cite this paper?

Betancourt Guerrero, B., Espinal Ruiz, D. J., \& Scarpetta Calero, G. (2020). Organizational characterization of craftsmanship in northern of Valle del Cauca. Cuadernos de Administración, 36(67), 4-15.

https://doi.org/10.25100/cdea.v36i67.8730

Cuadernos de Administración journal by Universidad del Valle is under licence Creative Commons ReconocimientoNoComercial-SinObrasDerivadas 4.0. Based in http://cuadernosdeadministracion.univalle.edu.co/ 